\title{
耳下腺外科における顔面神経の処理と対策
}

\author{
丘村熙・柳原 尚明

\section{Management of the Facial Nerve in Parotid Surgery}

\author{
Hiroshi Okamura and Naoaki Yanagihara
}

(Ehime University)

We operated on 86 parotid masses of different etiology during the past nine years and three months. Based on our surgical experiences, we established principles for managing the facial nerve in parotid surgery. In case of malignant tumors, a wide excision of the tumor with the surrounding soft tissue is of prime importance for controling the tumor. To achieve this purpose, the facial nerve was inevitably sacrificed with the tumor. When a tumor, even if it is benign, adheres to the facial nerve, the involved branches of the nerve should be resected to prevent recurrence of the tumor. When the facial nerve was sacrificed, nerve repair or muscle transfer technique was employed according to the extent of the removal of the nerve. Nerve grafting, total or partial, was indicated when the facial nerve was sacrificed in its extratemporal portion. On the other hand, muscle transfer technique (the temporalis, masseter and digastricus) with multiple fascial suspension was employed when the nerve was removed in its intra- and extra-temporal portions.

Key words: parotid surgery, facial nerve, nerve repair, muscle transfer

\section{はじめに}

耳下腺腫皕では手術治療が第一選択となる が，顔面神経に腫瘍が癒着したり，洨閴してい ると同神経の処理が重要な問題となる。著者ら は悪性腫瘍では顔而神経の全切除を原則とす るが，应性腫瘍でも腫瘍が同神経に痛着してい る洔には腫瘍の完全摘出を目的として，侍に神 経の部分切除を行うことにしている. しかし， かかる顔面神経の切除を行うと, 切除笨囲に応 じて顔面の機能や形態の再建を講じる必要があ る. 原則的には神経修復術を行うが，時に筋移 行術や，顔而吊り上げ術などの形成外科的手段 屯併用している。
以上の耳下腺外科における顔面神経の処理と 対策は, 過去 9 年間に著者らが行った耳下腺手 術86症例の経験に基づくものである。乙てにそ の詳細を述べ, 諸家の御批判を仰ぎたい.

\section{耳下腺手術の統計から}

刅和51年 10 月から同60年 12 月までの 9 年 3 力 月の間に著者らの施設で執刀した耳下腺手術は 86例で, 男女比は 1:1.5 と女性に多かった。 年齢分有は 5 歳から80歳で, 平均年粜令は 47.0 歳 であった。疾患の内訳（表 1 ）は, 多形腺腫が 38例と咠多であったが, 粘表皮腫を含む癌腫む 23例におよんだ。単一形腺腫の 9 例は腺りンパ 腫が 6 例で, 索状腺腫が 3 例であった。炎症は 
膿瘍および再発性慢性耳下腺炎で，根治を目的 として耳下腺摘出術を行った。その他の 5 例は 顔面神経䩪腫，リンパ管腫， benign lymphoepithelial lesionなどであった。なお，86例 の手術例中, 新鮮例は78例で, 再発例は 8 例で あった。後者の内訳は多形腺腫 3 例, 多形腺腫 内癌 3 例, 粘表皮腫および腺癌の各 1 例であっ た。

1. 顔面神経の切除例について

腫瘤摘出時に顔面神経を切除した症例は86例 中の33例であった。良性疾患では63例中の10例 で, そのうち 8 例は部分切除例, 2 例は全切除 例であった，前者は主に多形腺腫例で，後者は 顔面神経麻瘏を伴う深葉原発の巨大な多形腺腫 と侧頭骨外顔面神経鞘腫の例であった。粘表皮 腫を含む悪性腫瘍では23例の全例に腫瘍とと屯 に顔面神経を切除しており，全切除が22例を占 めている。乙れらの中枢側切断部位は, 側頭骨 外顔面神経主幹部が15例で, 残りの 7 例では腫 瘍が乳様突起内に浸潤しており，6 例が膝神経 節部， 1 例が内耳道内であった。部分切除例は 1 例で, 腫瘍が浅葉内の一部に限局した症例で あった。

2. 顔面神経切除後の再建法について 顔面神経切除後の再建法を表 2 亿示した。部

表 1 耳下腺手術症例

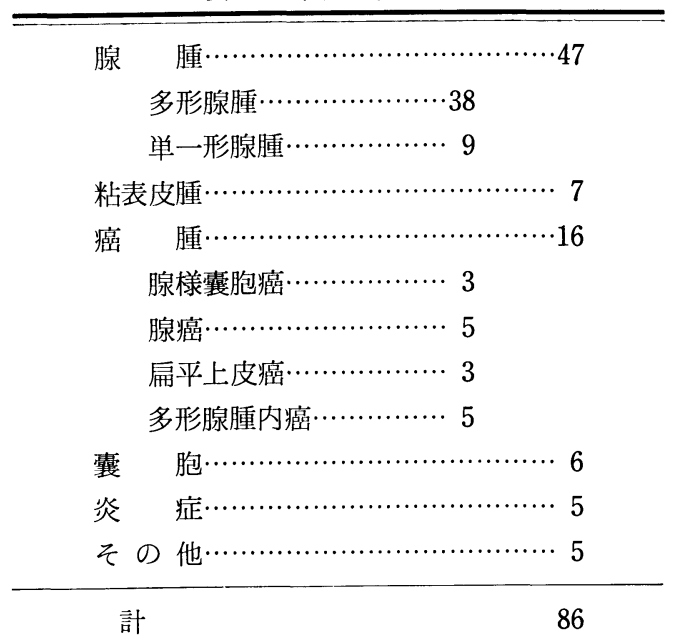

分切除例の 9 例中，第 2,3 次分岐部で切除し た 5 例には神経端々吻合術または神経部分移植 術を行い，第 4,5 次分岐部で切除した 4 例に は特別の処置をしなかった。放置例は顔面神経 叢の存在により切除神経の機能が代償されるむ のと判断したものである.

神経全切除例の 24 例では, 全神経移植術を 17 例に行い，このうち 3 例には咬筋むしくは顎二 腹筋の移行術を追加した。神経移植にあたって は可能なかぎり後述する funicular suture を 行った。残りの 7 例は腫煌の側頭骨内浸潤例 で，顔面神経の中枢側切断部が膝神経節部また は内耳道内であったので神経移植を行わなかっ た。このうち 3 例には，眼輪部に側頭筋，口角 部に咬筋および顎二腹筋を用いた筋移行術を行 い，さらに鼻唇溝部を中心に大腿筋膜による顔 面吊り上げ術を併用し，整容的・機能的再建を 計った。放置の 4 例は腫瘍の広範囲進展例で, 腫瘍制御の経過観察上顔而の機能と形態の再建 を計らなかった。

\section{3 . 術後成績}

(1)神経修複術

神経部分切除後の神経端々吻合例では麻痺回 復は艮好で，いずれも表情運動は完全回復し た。

神経移植後の麻痺回復程度については顔面神

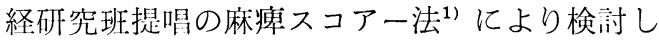
た（図 1)。神経部分移植例は神経切除範囲に

表 2 顔面神経切除後の処理法

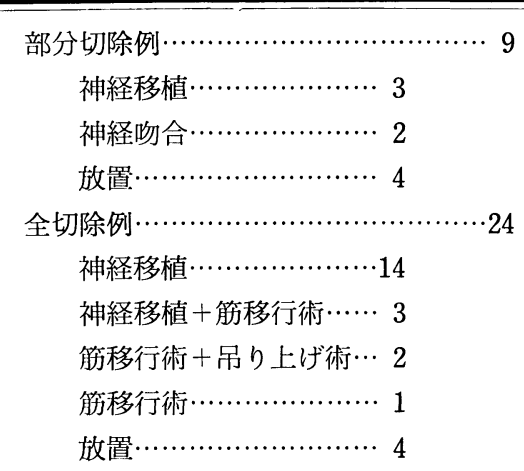


よって回復にいたるまでの期間が異なるもの の，いずれも36点（90\%）以上とほぼ完全回復 した. 一方, 神経全移植例でも図 2 に示すごと くかなり良好な機能回復が得られた。 しかし, その回復程度は部分移植例に比較すると劣るも のであった。神経全移植術の例では神経再支配 の徵候は術後 6 力月目位に現われ，機能回復に は 1 年を要するものといえる。 その後も回復は 進行し，安定状態に達するまでには少なくとも 2 年間の経過をみる必要がある。従来の神経移 植法と funicular suture によるものとを比較 すると, 後者の方が機能回復能はより良好で, その多くが麻瘏スコアーで30点 $(75 \%)$ 近くに 達していた。なお， 1 年以上経過しても麻痺ス コアーが20点に達しなかった症例はいずれも高 齢者例であった。

(2)筋移行術

神経移植不可能例には筋移行術之顔面吊り上 げ術を行ったが，図 3 に示すごとく安静時の対

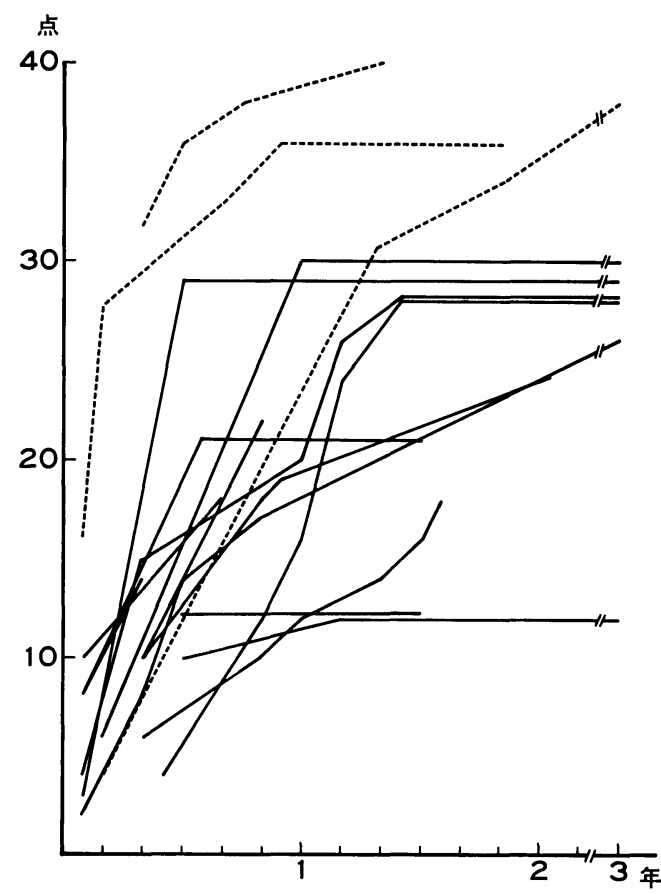

図 I神経移植後の麻㾇スコアーの推移. 点線は部分移植例, 実線は全移植例. 縦軸：麻瘏 スコアー, 横軸：術後観察期間.
称性のみならず，動的機能も或る程度再建され ており, 整容的, 機能的再建の初期の目的は達 成されていた。特に，側頭筋による眼瞼閉鎖運 動, 咬筋・顎二腹筋による口角運動は十分では ないにしても，日常生活には支障を来さない程 度の機能を賦与することができた。

\section{顔面神経の処理}

耳下腺手術後の主な合併症は Frey 症候群 と顔面神経麻瘏である。 Frey 症候群は耳下腺 手術後には高率に発症しうる不快な合併症であ るが, 術式の選択とそれに応じた予防策を講じ れば，発症率を極力抑えることができる ${ }^{2) 31}$.

一方, 顔面神経は耳下腺疾患の病態によっては 切除せざるをえないことがあり, 同神経を切除 すると, 術後の顔面神経麻瘦に対する対策が必 要になる。戸川 によれば耳下腺腫瘍手術の目 的は腫瘍の完全摘出はいうまでもなく, 術後に 障害を残さないか, 生じても最小限にとどめ, 必要に応じて顔面運動機能や形態を再建するに あるとしている，著者らの耳下腺手術屯腫瘍の 完全摘出に主眼をおき，必要とあれば躊躇する ことなく顔面神経を切除し, 切除範囲により一 定の方針で術後麻䗵を最小にすべく対策をとっ ている.

1. 顔面神経の切除

\section{(1)㢃性腫瘍}

良性腫瘍における顔面神経の切除については 異論のあるところかと考える。しかし，良性腫 瘍でも顔面神経に癒着している場合, 同神経の 温存に留意しすぎると，とりわけ多形腺腫では 術後腫瘍の再発は高率になる。著者らの手術症 例には他施設で手術を受けた 8 例の再発例を含 んでいるが， 3 例は多形腺腫であり，良性腫晹 といえどあ完全切除をおろそかにしてはならな い. 再発腫腸の摘出術となると顔面神経の温存 は殆ど不可能で, 同神経の犠牲は大きく, その 再建むきわめて困難となる。一方, 神経部分切 除後の麻綼回復能は先述の通り良好で, ほぼ完 全回復を期待できる。かかる著者らの臨床経験 に基づき，良性腫瘍でも腫瘍が顔面神経に瘜着 

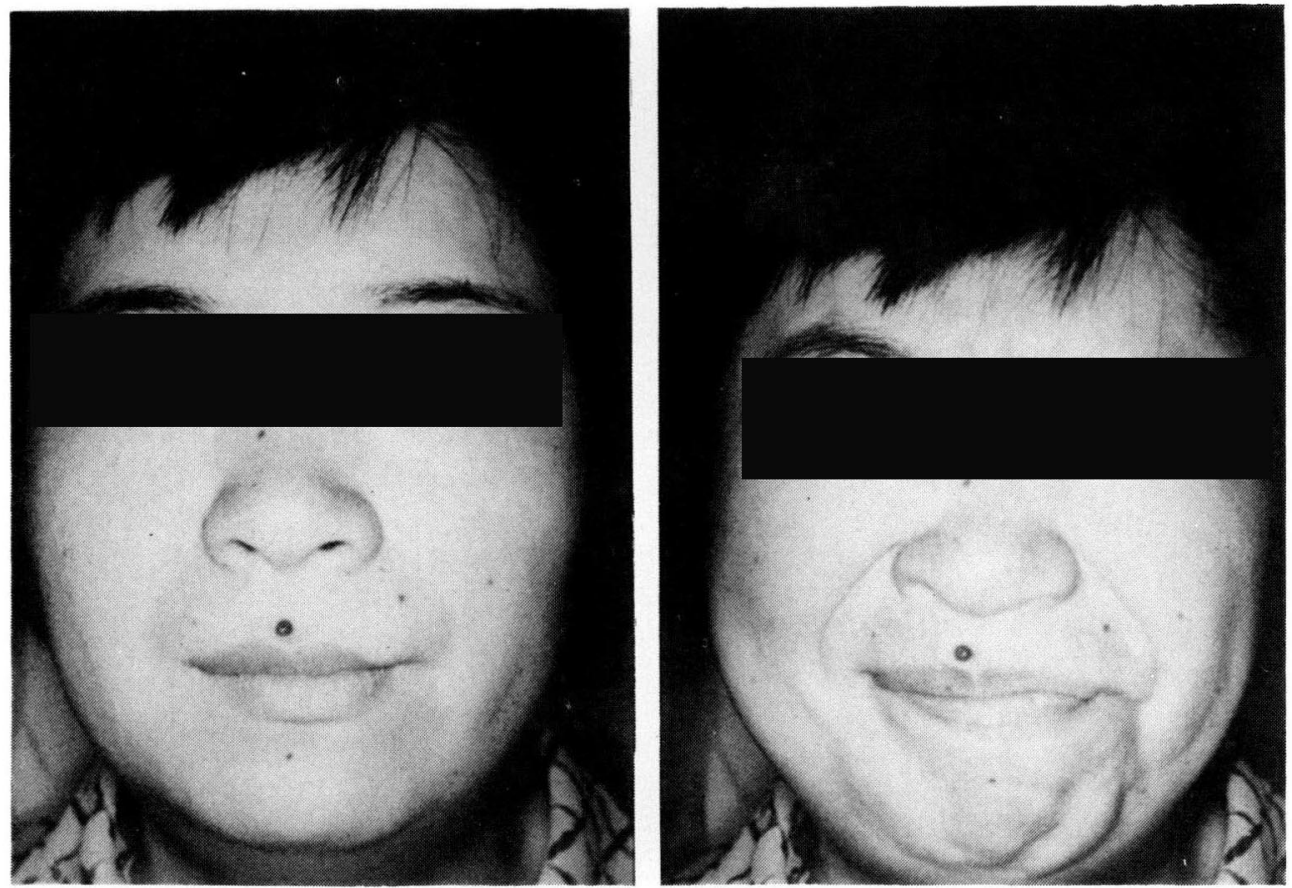

図 2 神経全移植 (funicular suture) 後1.5年目（術側：右） 麻痺スコアー30点に回復している。
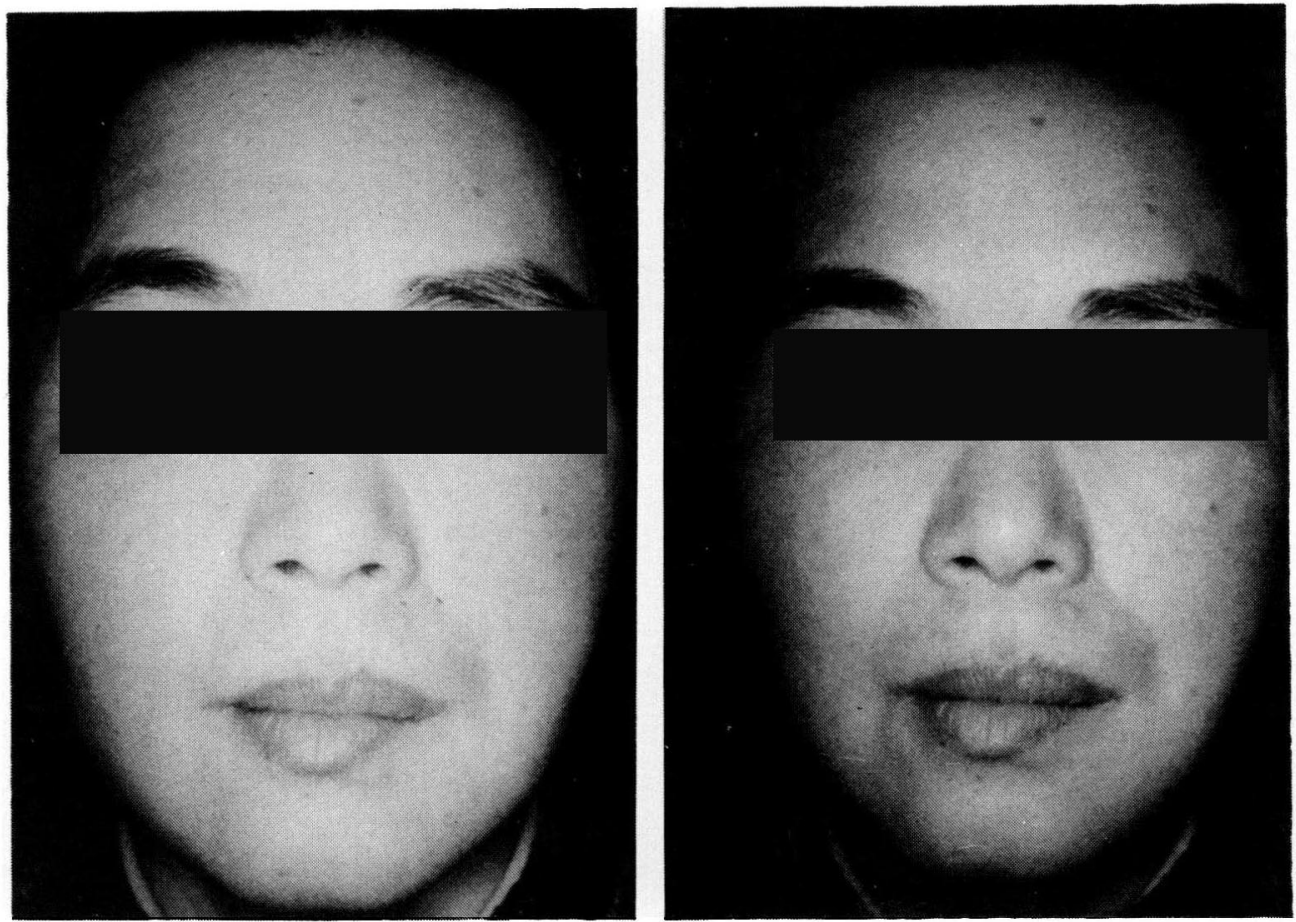

図 3 筋移行術（側頭筋と咬筋）および筋膜による鼻唇溝部の 吊り上げ術後 7 力月目 (術側：左). 
している埸合には完全摘出を目的として同神経 の切除を行い，切除範国に応じた対策を行うこ とにしている.

(2)悪性腫瘍

悪性腫煌では顔面神経の全切除を基本方針と している。耳下腺覀性腫瘍では放射線療法, 化 学療法による治療効果はそしく，根治を期する には初回手術で徽底した切除を計るべきと考え る. 粘表皮腫や腺房細胞癌の中には low grade malignancy があり，乙れらに対し顔面神経の 全切除を行うことには批判の问きもあるが, 術 前にも，術中病理診断でも low grade malignancy と判定することは困難であるので, 顔 㴁神経の全切除を行い, 癌腫の完全摘出を確実 にしている。神経の切除範囲, 特に中枢側につ いては，腫瘍が側頭骨外に限局していれば茎乳 哭孔近くの顔而神経主翰で切断し，腫瘍が顔洫 神経に浴って側頭骨内に進展している埸合には 腫瘍の広範切除のために少なくと屯膝神経節ま で切除することにしている.

2 . 顔面神経切除後の再建法

顔面神経切除後の機能と形態の再建法につい

て，著者らの基本方針（表 3 ）を以下に紹介す る。

\section{(1)神経修復法}

顔面神経切除後の機能再建法の骨子は神経移 植術であるが, 同神経の切除範囲によって治療 方針は自ら異なる。

a . 神経部分切除の塄合
端々吻合が可能であればこれを行うが，不可 能な塄合には以下の方針で臨む. 第 2 次, 第 3 の分岐部での切除では神経部分移植術を行う. 移植神経片には大耳介神経を用いる。神経縫合 は epineural suture で, 手術用顕微鏡下にナ イロン糸10-0を用いて, 中枢部は $2 \sim 3$ 針, 末梢部は $1 \sim 2$ 針かける. 第 4 次, 第 5 次の分 岐部の切除では顔面神経叢により術後に機能は 十分代償されるので特に処置をほどこす必要は ない.

b ．神経全切除の場合

神経全切除例では全神経移植術を行うが，そ の邀心は側喕等外切除例に限られる。移植神経 片には原則として大耳介神経を用いるが，全切 除例は主として墨性腫瘍であるので, 頸部郭清 術を併用することが多く，十分な移植片を採取 できない堤合もあり，必要に忍じて腓腹神経を 利用することがある。

神経縫合は可能なかぎり funicular suture

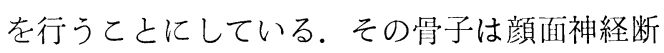
端，移植神経枝扝よび顔面神経末梢端の fu-

表 3 顔面神経切除後の再建法の基本方針

神経移植可能例

神経移植術十筋移行術（顎二腹筋）

神経移植不可能例

筋移行術

側頭筋，咬筋，顎二腹筋

顔面吊り上げ術
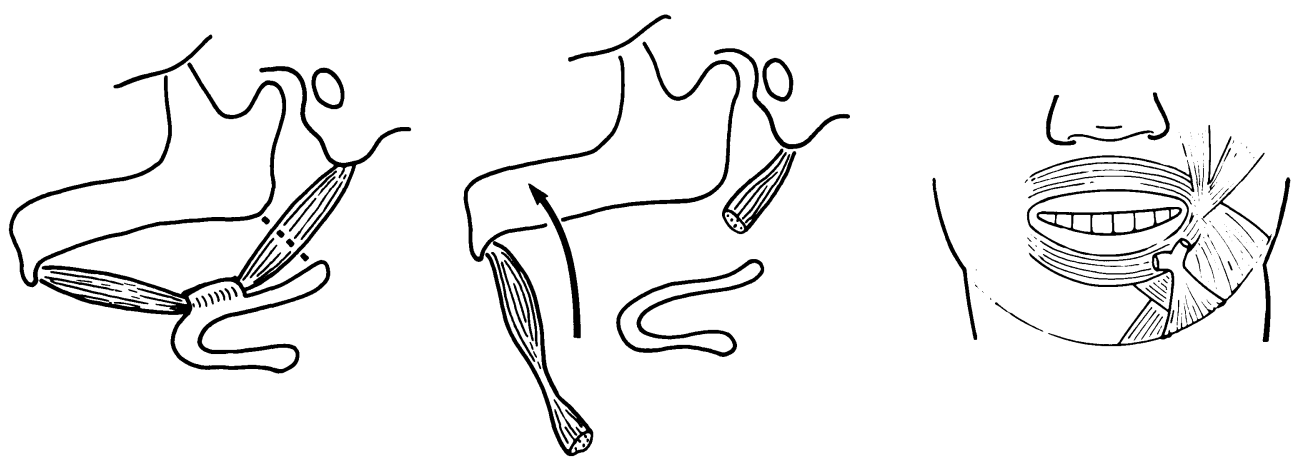

図 4 顎二腹筋移行術 ${ }^{13}$ ) の模式図. 
niculus の太さを適合させることで，言いかえ れば太い funiculus は太いものに, 細いもの は細いものに縫合することである，少なくとも 側頭・煩骨枝，煩枝下顎枝には神経移植をする ことにしている，術後成績については，従来の 縫合法と比較検討でさる段階には達していない が，経験的により満足すべき機能回復が得られ ている。なお，術後にはリハビリテーションの 一つとして，顔面筋の電気刺激を行っている. これは電気刺激により顔面筋への血流を補給 し, 筋萎縮を防御するためである ${ }^{5)}$. 神経移植 後機能回復にいたるまでには 1 年近くを要する ので，乙の間の機能障邫をできるかぎり軽減す べく, 最近では咬筋や㖽二腹筋の移行術を併用 し, 摂食時の口角よりの液体の漏れを防いでい る.また, 先に述べた通り高秢者では機能回復 の程度が良くないので, かかる症例にも筋移行 術を追加した方が望ましいと考えている.

(2)筋移行術および顔面吊り上げ術

腫煌が顔面神経に沿って側頭骨内に浸潤して いる場合には, 腫瘍の広籁切除を目的として少 なくとも膝神経節まで切除しているので, 神経 移植術は不可能となる。加る場合には健側顔 面神経を利用した交叉性顔面神経移植術 ${ }^{6}$, 舌 下神経, 副神経, 横隔膜神経, 舌咽神経などと の吻合法, 遊離筋肉移植法 ${ }^{7)}$, 微小血管神経縫 合による筋肉移植法 ${ }^{8)}$ など種々の方法が紹介さ れている。しかし, 耳下腺悪性腫焬の場合, 失 う機能をできるだけ少なくすること，再建法が できるだけ簡単であるべきとの考えから，筋移 行術之顔面吊り上げ術を用いた形成外科的手段 で対応している．筋移行術の目的はその筋自体 による運動能の賦与と sprouting による顔面 筋への neurotization を期待している.

筋移行術は眼輪部之口角に行っている。側頭 筋移行術は眼瞼運動の賦与を期待して行う。本 術式は Gillies ${ }^{9)}$ にって始められ, Ander$\operatorname{sen}^{10)}$ によって一般化されたもので, 方法自体

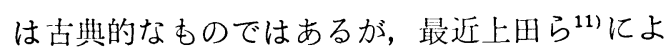
りその有用性が再評価されている。手術方法も
簡単で, 比較的満足できる機能が得られる。口 角には咬筋 ${ }^{12)}$ 之顎二腹筋移行術を行い, 口角の 牽引と外方運動を計っている. 顎二腹筋移行術

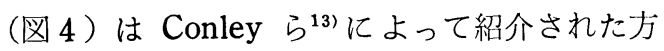
法で口唇下制筋の代用として用いられる，咬筋 移行術のみでは口角が挙上されすぎるので顎二 腹筋移行術の併用により均整を計っている. こ れらの筋移行術だけでは安静時の顔面の対称性 が十分でないので，大腿筋膜を用いた顔面吊り 上げ術を加えている ${ }^{14)}$. 主に挙上する部位は鼻 唇溝部である。

以上，耳下腺手術における顔面神経の処理之 対策について，著者らの基本方針を紹介した。 顔面神経切除後の機能再建法については比較的 満足すべき成績をおさめているが，なお改良す べき所が少なくない，特に, 神経移植不可能例 に対して,より動的機能の再建法の開発が望ま れる。

\section{まとめ}

耳下腺手術に抢汀る顔酉神経の処理力法と同 神経切除時の再建方法について著者らの基本方 針を紹介した。良性腫瘍が顔面神経に痖着して いる場合には，腫瘍の完全摘出を目的として同 神経の部分切除を行い, 悪性腫煌では初回手術 での根治を目的として同神経の全切除を行って いる.

顔面神経部分切除の埸合には，端々吻合また は神経部分移植術を行う。同神経の側頭外全切 除では全神経移植を行うが, 神経縫合法の骨子 は funicular suture である.なお, 最近では 咬筋・顎二腹筋移行術を採用している。顔面神 経を広範に切除した場合には神経移植が不可能 なので, 眼輪部には側頭筋, 口角部には咬筋・ 顎二腹筋の筋移行術を行い, さらに鼻唇溝部を 中心に大腿筋膜を用いた顔面吊り上げ術の併用 で対処している。

本論文の要旨は第 9 回日本頭頸部腫場学会で口演し た. 


\section{美考文献}

1) 柳原尚明, 他：顔面神経麻軒程度の判定基準に関 する研究. 日耳鼻 $80: 799 \sim 805,1977$.

2) 丘村 熙, 他：人凍結乾燥硬膜を利用した Frey 症候群の治療. 耳喉 $54: 225 \sim 230,1982$.

3 ) 藤原康雄, 他：ヒト凍結乾燥硬膜による Frey 症 候群の予防. 耳喉 $57: 349 \sim 352,1985$.

4 ) 戸川 清 : 耳下腺腫瘍手術の要領と顔面神経の処 理. 耳下腺腫煌の臨床 (奥田 稔編)． 143～159 頁, 医学教育出版社, 東京, 1984 .

5) Okamura $\mathrm{H}$, et al: Thermodynamics in facial palsy. Disorders of the Facial Nerve (ed by Graham MD and House WF). pp 107 113, Raven Press, New York, 1982.

6 ）山本悦生：交文性顔面神経移植術. 日形会誌 I : 267〜275, 1981.

7) Thompson $\mathrm{N}$ : Autogenous free grafts of skeletal muscle. A preliminary experimental and clinical study. Plast Reconstr Surg 4I: 11 27, 1971.

8) Harii K, et al : Free gracilis muscle transplantation with microneurovascular anastomosis for the treatment of facial paralysis. Plast Reconstr Surg 57:133 143, 1976.

9) Gillies H, et al : Facial paralysis. The Prin- ciple and Art of Plastic Surgery (ed by Gillies H, et al). pp 600 609, Little Brown and Company, Boston, 1957.

10) Andersen JG : Surgical treatment of lagophthalmos in leprosy by the Gillies temporalis transfer. Br J Plast Surg 14:339 345, 1961.

11）上田和毅，他：眼輪筋麻舫に対する側頭筋移行術 の評価. 日形会誌 $3: 48 \sim 55,1983$.

12) Freeman SS : Facial palsy. Reconstructive Plastic Surgery (ed by Converse JM). pp 1149 1154, WB Saunders Co., 1964.

13) Conley $\mathrm{J}$, et al : Paralysis of the mandibular branch of the facial nerve. Plast Reconstr Surg $70: 569 \sim 577,1982$.

14) Yanagihara $N$, et al : Multiple fascial strips for suspension of forehead and mouth in facial palsy. Disorders of the Facial Nerve (ed by Graham MD and House WF). pp 533 〜52, Raven Press, New York, 1982.

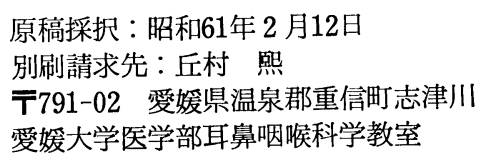

